University of Wollongong

Research Online

Faculty of Law, Humanities and the Arts Papers (Archive)

Faculty of Arts, Social Sciences \& Humanities

$1-1-2019$

International environmental law principles relevant to exploitation activity in the Area

Robin M. Warner

University of Wollongong, rwarner@uow.edu.au

Follow this and additional works at: https://ro.uow.edu.au/lhapapers

Part of the Arts and Humanities Commons, and the Law Commons

Research Online is the open access institutional repository for the University of Wollongong. For further information contact the UOW Library: research-pubs@uow.edu.au 


\title{
International environmental law principles relevant to exploitation activity in the
}

\section{Area}

\author{
Abstract \\ The International Seabed Authority is responsible for providing effective protection for the marine \\ environment from the harmful effects of activities in the Area under Article 145 of UNCLOS. To meet this \\ challenge, it must determine the relevant environmental governance principles applicable to each stage of \\ an exploration and exploitation activity and how they can be operationalized in practical terms. This \\ article discusses some key principles of international environmental law and management which are \\ potentially relevant to the exploitation process and in particular the approval of a plan of work for \\ exploitation activities. It also examines the potential legal thresholds for approval or denial of a proposed \\ plan of work for exploitation activity in the Area.
}

\section{Keywords}

exploitation, area, relevant, activity, principles, law, environmental, international

\section{Disciplines}

Arts and Humanities | Law

\section{Publication Details}

Warner, R. (2019). International environmental law principles relevant to exploitation activity in the Area. Marine Policy, Online First 1-7. 
Some International Environmental Law Principles Relevant to Exploitation Activities in the Area

\section{Professor Robin Warner}

Australian National Centre for Ocean Resources and Security (ANCORS)

University of Wollongong, Australia

\section{Abstract}

The International Seabed Authority is responsible for providing effective protection for the marine environment from the harmful effects of activities in the Area under Article 145 of UNCLOS. To meet this challenge, it must determine the relevant environmental governance principles applicable to each stage of an exploration and exploitation activity and how they can be operationalized in practical terms. This article discusses some key principles of international environmental law and management which are potentially relevant to the exploitation process and in particular the approval of a plan of work for exploitation activities. It also examines the potential legal thresholds for approval or denial of a proposed plan of work for exploitation activity in the Area.

\section{Keywords}

International environmental law principles, the Area, exploitation activity, legal thresholds for approval of exploitation in the Area

\section{Introduction}

In accordance with Article 145 of the UN Convention on the Law of the Sea (LOSC) ${ }^{1}$, the International Seabed Authority (ISA) is responsible for ensuring effective protection for the marine environment from harmful effects which may arise from activities in the Area. An essential element of an effective environmental strategy towards this end is the approval or rejection of applications for exploration and exploitation activities based on clear conditions. This strategy should include substantive criteria as preconditions for the approval of an

\footnotetext{
${ }^{1}$ United Nations Convention on the Law of the Sea (opened for signature 10 December 1982, entered into force 16 November 1994) 1833 UNTS 3 (LOSC).
} 
exploitation activity. These substantive criteria are of critical importance as they will determine an effective level of protection from the harmful effects which may arise from exploitation activities in the Area, and the acceptable level of adverse impacts on the marine environment from such activities. One of the key challenges for the ISA is to strike an equitable balance between its responsibilities to develop the mineral resources of the Area for the benefit of mankind as a whole and to provide effective protection for the marine environment from the harmful effects of activities in the Area. To meet this challenge, the ISA must determine the relevant environmental governance principles applicable to each stage of an exploration and exploitation activity and how they can be operationalized in practical terms. This paper focuses on the substantive environmental criteria relevant to the approval or rejection of a plan of work for exploitation. It will consider the content of normative principles of international environmental law and generally accepted principles of environmental management which apply to activities in the Area and how they should be reflected in the substantive criteria for approval or rejection of an application for an exploitation activity. It will also consider the potential legal thresholds for approval or denial of a proposed plan of work for exploitation activity in the Area taking into account these principles.

\section{Normative Principles of International Environmental Law and Generally} Accepted Approaches to Environmental Management Applicable to Activities in the Area

States Parties of the LOSC have the overarching obligation under Article 192 of the LOSC to protect and preserve the marine environment. This broad obligation is applicable to all parts of the marine environment including the Area. It is supplemented by other articles in Part XII of the LOSC requiring States to take all measures necessary, consistent with the LOSC to prevent, reduce and control pollution of the marine environment from any source including activities in the Area. ${ }^{2}$ Such measures are to include those necessary to protect and preserve rare and fragile ecosystems as well as the habitat of depleted, threatened or endangered species and other forms of marine life. ${ }^{3}$ The particular sectoral context of the Area is recognized in Article 209 of the LOSC which provides that international rules, regulations and procedures shall be established in accordance with Part XI of the LOSC to prevent reduce

\footnotetext{
${ }^{2}$ LOSC, Article 194(1).

${ }^{3}$ LOSC, article 194(5)
} 
and control pollution of the marine environment from activities in the Area. Under this article, States must also adopt regulations rules and procedures no less effective than the international rules for vessels, installations, structures and devices flying their flag or operating under their authority undertaking activities in the Area.

The environmental protection responsibilities of the ISA are made more specific in Article 145 of the LOSC which provides that necessary measures shall be taken with respect to activities in the Area to ensure effective protection for the marine environment from harmful effects which may arise from such activities. To this end, the Authority must adopt appropriate rules regulations and procedures for:

(a) the prevention reduction and control of pollution and other hazards to the marine environment, including the coastline, and of interference with the ecological balance of the marine environment, particular attention being paid to the need for protection from harmful effects of such activities as drilling, dredging, excavation, disposal of waste, construction and operation of maintenance of installations, pipelines and other devices related to such activities;

(b) the protection and conservation of the natural resources of the Area and the prevention of damage to the flora and fauna of the marine environment.

In developing regulations for exploration in the Area, the Authority has taken into account normative principles of international environmental law and environmental management as they evolve. ${ }^{4}$ The underlying principles and international law obligations which have informed the development of the ISA's environmental management approach, reflected in the Mining Code, include the common heritage of mankind, the precautionary principle, prior environmental impact assessment, conservation and sustainable use of biodiversity and transparency. ${ }^{5}$ This article discusses some key principles of international environmental law and management which are relevant to the exploitation process and in particular the approval of a plan of work for exploitation activities.

\subsection{The Common Heritage of Mankind}

\footnotetext{
${ }^{4}$ Michael Lodge, 'Protecting the Marine Environment of the Deep Seabed' in R. Rayfuse (ed.) Research Handbook on International Marine Environmental Law (Routledge, 2015) 168.

${ }^{5}$ Ibid, 166.
} 
Article 136 of the LOSC provides that "the Area and its resources are the common heritage of mankind." Although the common heritage of mankind (CHM) is not defined in the LOSC, its various dimensions are further explained and captured in subsequent provisions of Part XI of the LOSC. A central aim of the CHM concept is to ensure intra-generational equity and sharing of the benefits of seabed mining. ${ }^{6}$ Jaeckel comments on the balance to be struck in implementing the CHM principle between "the equitable sharing of any benefits from seabed mining as well as the preservation of the marine environment for present and future generations. "7 The tension between these two elements of the ISA's responsibility to implement the CHM principle is also reflected in the Advisory Opinion of the Seabed Disputes Chamber of the International Tribunal on the Law of the Sea (ITLOS) on Responsibilities and Obligations of States Sponsoring Persons and Entities with Respect to Activities in the Area, which recognised that although socio-economic considerations play a role, they should not compromise environmental protection efforts. ${ }^{8}$

The CHM principle could be considered to support a more holistic and regional planning approach to developing the mineral resources of the Area in an environmentally sustainable manner employing tools such as marine spatial planning, strategic environmental assessment (SEA) for different regions of the Area and environmental impact assessment (EIA) for specific development proposals. A precautionary approach should be adopted by the Authority to ensure that proposed exploitation activities are in the long-term interest of humankind. This would include an assessment of alternatives to deep seabed mining, such as land-based minerals and technological solutions to potential increases in mineral demand. At the plan of work for exploitation stage, the operationalisation of the CHM principle would appear to require that the Authority take into account a range of matters in relation to applicants. These include both their financial and technical capabilities to carry out successful exploitation activities as well as their ability to ensure effective protection for the marine environment from harmful effects which may arise from their activities. In the most recent draft of the Exploitation Regulations issued by the Authority in July 2018, the applicant for a

\footnotetext{
${ }^{6}$ LOSC, Article 140; Jutta Brunnee, 'Common Areas, Common Heritage, and Common Concern' in Daniel Bodansky et al (eds), The Oxford Handbook of International Environmental Law (Oxford University Press, 2007) 561.

${ }^{7}$ Aline Jaeckel, The International Seabed Authority and the Precautionary Principle (Brill Nijhoff, 2017$) 52$.

${ }^{8}$ Responsibilities and Obligations of States Sponsoring Persons and Entities with Respect to Activities in the Area (Advisory Opinion) (Seabed Disputes Chamber, Case No. 17, 1 February 2011), https://www.itlos.org/fileadmin/itlos/documents/cases/case_no_17/17_adv_op_010211_en.pdf, paragraph 158 (Advisory Opinion).
} 
plan of work must provide the Authority with a number of documents relating to their ability to ensure such protection of the marine environment. These include an Environmental Impact Statement, an Environmental Management and Monitoring Plan and a Closure Plan. ${ }^{9}$

\subsection{Ecosystem Approach}

The ecosystem approach is a science based environmental management strategy which encompasses the essential structure, processes, functions and interactions among organisms and their environment. ${ }^{10}$ Essentially it is about managing an ecosystem as a whole rather than managing individual components of the ecosystem separately. While Article 194(5) of the LOSC hints at this management approach in its reference to "the measures necessary to protect and preserve rare and fragile ecosystems as well as the habitat of depleted, threatened or endangered species and other forms of marine life", it was not until the 1987 Report of the World Commission on Environment and Development (Brundtland Report) ${ }^{11}$ and the 1992 Convention on Biological Diversity $(\mathrm{CBD})^{12}$ that this approach gained currency in international environmental law and mangement. It now features in many international law instruments including the UN Fish Stocks Agreement, ${ }^{13}$ and is a widely accepted approach to environmental management which should be taken into account in developing the ISA's environmental regulations for the exploitation phase of deep seabed mining.

The ecosystem approach is reflected as a fundamental principle in the draft Exploitation Regulations. Regulation 2(5)(c) provides:

„In furtherance of and consistent with Part XI of the Convention and the Agreement, the fundamental principles of these Regulations are, inter alia, to:....

\footnotetext{
${ }^{9}$ ISA, Draft Regulations on Exploitation of Mineral Resources in the Area, ISBA/24/LTC/WP.1/REV.1, 9 July 2018, https://www.isa.org.jm/document/isba24ltcwp1rev1, Regulations 7(3)(d)(h) and (i).

${ }^{10}$ Convention on Biological Diversity, Ecosystem Approach, https://www.cbd.int/ecosystem/

${ }^{11}$ World Commission on Environment and Development (WCED), Our Common Future, (Oxford 1987).

${ }^{12}$ Convention on Biological Diversity (opened for signature 5 June 1992, entered into force 29 December 1993) 1760 UNTS 79 (CBD).

${ }^{13}$ Agreement for the Implementation of the Provisions of the United Nations Convention on the Law of the Sea of 10 December 1982 relating to the Conservation and Management of Straddling Fish Stocks and Highly Migratory Fish Stocks (opened for signature 4 August 1995, entered into force 11 December 2001), 2167 UNTS 3, Article 5(d) and (e) (UN Fish Stocks Agreement).
} 
5. Provide for the effective protection of the Marine Environment from the harmful effects that may arise from Exploitation, in accordance with the Authority's environmental policy and regional environmental management plans, if any, based on the following principles:... (c) The application of an ecosystem approach "14

Defining clear objectives and standards for effective ecosystem based management of particular regions within the Area will be critical to implementation of this approach. This could be done in a set of guidelines accompanying the environmental regulations for the exploitation phase. An ecosystem approach would require an assessment of the impacts of minerals exploitation on not only a single mine site or contract area but of the entire ecosystem, which may be regional or sub-regional. An ecosystem based approach would also need to take into account the cumulative and synergistic impacts of diverse human activities on the marine environment of the Area over time. This could be achieved by employing mechanisms such as regional environmental management plans and SEAs of particular regions within the Area against which to evaluate the applicant's plan of work for exploitation. At the application for a plan of work stage, the requirement reflected in the current draft Exploitation Regulations for applicants to accompany their application with an environmental impact statement and an environmental management and monitoring plan prepared in accordance with the detailed Annex IV of the draft Exploitation Regulations is one of the principal means of implementing an ecosystem approach. ${ }^{15}$

\subsection{Precautionary Approach}

The ISA, sponsoring States, and contractors are required to apply a precautionary approach as reflected in Principle 15 of the Rio Declaration on Environment and Development to activities in the Area. ${ }^{16}$ Principle 15 provides:

'In order to protect the environment, the precautionary approach shall be widely applied by States according to their capabilities. Where there are threats of serious or irreversible

\footnotetext{
${ }^{14}$ Draft Exploitation Regulations, above note 9, Regulation 2(5)(c).

${ }^{15}$ Ibid, Regulation 7(3)(d) and (h), 46 bis and ter, Annex IV.

${ }^{16}$ Principle 15 of the Rio Declaration on Environment and Development, UN Doc. A/CONF/151/26 (Vol.1), http://www.un.org/documents/ga/conf151/aconf15126-1annex1.htm
} 
damage, lack of full scientific certainty shall not be used as a reason for postponing cost effective measures to prevent environmental degradation."

The ISA Nodules Regulations 31(2) and the Sulphides and Crusts Regulations 33(2), state that sponsoring States and the Authority "shall apply a precautionary approach, as reflected in Principle 15 of the Rio Declaration" in order "to ensure effective protection for the marine environment from harmful effects which may arise from activities in the Area" ${ }^{17}$ Contractors are also required to implement a precautionary approach under ISA Nodules Regulations 31(5) and the Sulphides and Crusts Regulations 33(5).This obligation for sponsoring States and the Authority was endorsed by the Seabed Disputes Chamber of ITLOS in its Advisory Opinion on the Responsibilities and Obligations of States Sponsoring Persons and Entities with Respect to Activities in the Area. ${ }^{18}$ The obligation to apply a precautionary approach is reflected in the requirements imposed on applicants for exploration contracts. Prior to the commencement of exploration activities the contractor is required, to submit a preliminary assessment of the possible impact of the proposed exploration activities on the marine environment and a description of the programme for oceanographic and environmental baseline studies that would enable an assessment of the potential environmental impact, including, but not restricted to, the impact on biodiversity, of the proposed exploration activities. ${ }^{19}$ The exploration regulations, however, are not prescriptive as to the components of the EIA process although the ISA has issued Recommendations for the Guidance of Contractors on EIA. ${ }^{20}$ In addition, the preliminary EIA process for exploration contractors in the Area has not so far been subject to public notification or participation. ${ }^{21}$

The exploitation phase of activities in the Area portends a much higher risk of adverse impacts to the marine environment and therefore requires the application of a more detailed and stringent approach to assessing the risks to the marine environment from proposed

\footnotetext{
${ }^{17}$ Regulations on Prospecting and Exploration for Polymetallic Nodules in the Area (Nodules Regulations), ISBA/19/C/17, 22 July 2013, available at https://www.isa.org.jm/sites/default/files/files/documents/isba-19c17_0.pdf; Regulations on Prospecting and Exploration for Polymetallic Sulphides in the Area (Sulphides Regulations), ISBA/16/A/12/Rev.1, 15 November 2010 https://www.isa.org.jm/sites/default/files/files/documents/isba-16a-12rev1_0.pdf; Regulations on Prospecting and Exploration for Cobalt-rich Ferromanganese Crusts in the Area (Crusts Regulations), ISBA 18/A/11, 22 October 2012, https://www.isa.org.jm/sites/default/files/files/documents/isba-18a-11_0.pdf

${ }^{18}$ Advisory Opinion, above note 8, paragraph 141.

${ }^{19}$ Nodules Regulations 18(b) and (c); Sulphides and Crusts Regulations 20(b) and (c).

${ }^{20}$ ISA, Recommendations for the guidance of contractors for the assessment of the possible environmental impacts arising from exploration for marine minerals in the Area, ISBA/19/LTC/8, 1 March 2013, https://www.isa.org.jm/sites/default/files/files/documents/isba-19ltc-8_0.pdf

${ }^{21}$ Jaeckel, above note 7, 261-262.
} 
exploitation activities. The current draft Exploitation Regulations contains the following obligation to be applied by the Authority, sponsoring States and contractors:

“The Authority, sponsoring States and Contractors shall each, as appropriate, plan, implement and modify measures necessary for ensuring the effective protection of the Marine Environment from harmful effects under article 145 of the Convention in respect of activities in the Area. To this end, they shall:

(a) Apply the precautionary approach, as reflected in principle 15 of the Rio Declaration on Environment and Development, to the assessment and management of risk of harm to the Marine Environment from Exploitation in the Area."22

The more extensive environmental requirements imposed on applicants for a plan of work in the draft Exploitation Regulations reflect the higher levels of potential risk involved to the marine environment in the exploitation phase. Under the current draft, applicants must identify the geographical limits of the areas of the marine environment likely to be affected by their exploitation activities, including the direct, indirect and cumulative impact areas and establish an adequate environmental baseline of the environmental impact areas against which to assess the likely environmental impacts and to determine the necessary measures, management objectives and responses for the effective protection of the marine environment from exploitation activities. ${ }^{23}$ The EIA process is discussed in the next section as a key component of implementing the precautionary approach at the application stage.

Regulation 14(2) of the current draft Exploitation Regulations also requires the Legal and Technical Commission (LTC) of the ISA to determine following its review of an application, if the Environmental Plans in a proposed Plan of Work for exploitation: "provide for the effective protection of the Marine Environment in accordance with article 145 of the Convention, including through the application of a precautionary approach and Good Industry Practice."

\subsection{Environmental Impact Assessment}

\footnotetext{
${ }^{22}$ Draft Exploitation Regulations, above note 9, Regulation 46(a).

${ }^{23}$ Ibid, Annex IV.
} 
The general obligation to conduct an EIA of activities with the potential for significant harm to the marine environment is contained in Article 206 of the LOSC which provides:

"When States have reasonable grounds for believing that planned activities under their jurisdiction or control may cause substantial pollution of or significant and harmful changes to the marine environment, they shall as far as practicable, assess the potential effects of such activities on the marine environment and shall communicate reports of the results of the assessments in the manner provided in article 205."

In the context of activities in the Area, the requirement to conduct an EIA has been recognised as a customary international law obligation of sponsoring States by the Seabed Disputes Chamber of ITLOS in its Advisory Opinion. ${ }^{24}$ The key components of an EIA process are incorporated in Regulations 46 and Annex IV of the current draft Exploitation Regulations. Initially, applicants must prepare an environmental impact statement, an environmental management and monitoring plan and closure plan which includes the information prescribed in Annex IV of the current draft Exploitation Regulations. Under regulation 11(1) of the current draft Exploitation Regulations:

“1. The Secretary-General shall, within seven Days after determining that an application for the approval of a Plan of Work is complete under regulation 10: (a) Place the Environmental Impact Statement, the Environmental Management and Monitoring Plan and the Closure Plan on the Authority's website for a period of 60 Days, and invite members of the Authority and Stakeholders to submit comments in writing in accordance with the Guidelines; (b) Provide comments by members of the Authority and Stakeholders and any comments by the Secretary-General to the applicant for its consideration; and (c) Consult with the applicant, who may revise the Environmental Plans in response to comments made by members of the Authority, Stakeholders or the Secretary-General within a period of 60 Days following the close of the comment period."

The LTC then examines the Environmental Plans in the light of the comments made by members of the Authority and Stakeholders, any responses by the applicant and any additional information or comments provided by the Secretary-General and determines whether the Environmental Plans provide for the effective protection of the Marine

\footnotetext{
${ }^{24}$ Advisory Opinion, above note 8, paragraph 141.
} 
Environment in accordance with article 145 of the Convention, including through the application of a precautionary approach and Good Industry Practice. ${ }^{25}$

Prior to submitting an application for approval of a Plan of Work, applicants must conduct an EIA and prepare an EIS guided by the template set out in Annex IV. The EIS Executive summary should include:

(a) A description of the proposed development and its objectives;

(b) Economic, financial and other benefits to be derived from the project;

(c) Anticipated impacts of the activity (physicochemical, biological, socioeconomic);

(d) Mitigation measures to minimize environmental impacts;

(e) Linkages with the development of the Environmental Monitoring and Management Plan; and

(f) Consultation undertaken with other parties. $^{26}$

The draft Exploitation Regulations also provide the opportunity at different stages of the EIA process for stakeholders to have input in the process and for the applicant to respond to their submissions. ${ }^{27}$ "Stakeholder" means a natural or juristic person or an association of persons with an interest of any kind in, or who may be affected by, the proposed or existing exploitation activities under a Plan of Work in the Area, or who has relevant information or expertise. “28

This raises the question of whether the provisions on access to information for interested persons during the EIA process in the draft Environmental Regulations fulfil the widely accepted norms of public notification and consultation in an EIA process.

\subsection{Best Available Scientific Evidence}

Requirements for science based decision-making are found in many international environmental law treaties. ${ }^{29}$ This requirement is often expressed as an obligation to base

\footnotetext{
${ }^{25}$ Draft Exploitation Regulations, above note 9, Regulations 14(1) and (2).

${ }^{26}$ Ibid, Annex IV Executive Summary.

${ }^{27}$ Ibid, Regulations 11 and 14(1).

${ }^{28}$ Ibid, Schedule 1, definition of "Stakeholder."

${ }^{29}$ Jacqueline Peel, Science and Risk Regulation in International Law (Cambridge University Press, 2010) 111. In the marine environmental field these treaties include the 1980 Convention on the Conservation of Antarctic
} 
decisions on the "best available scientific evidence." In the context of an application for a plan of work for exploitation activities in the Area, both the applicant and the Authority are required to take into account the best scientific information available to them in their evaluation and management of risks to the marine environment. ${ }^{30}$ This is also reflected as a fundamental principle in Regulation 2 (6) of the current draft Exploitation Regulations. "Best available scientific evidence" is defined in Schedule 1 of the draft Exploitation Regulations as:

"the best scientific information and data accessible and attainable that, in the particular circumstances, is of good quality and objective, within reasonable technical and economic constraints and is based on internationally recognized scientific practices, standards, technologies, and methodologies."

Although the draft Exploitation Regulations do require the applicant and the Authority to take into account the best scientific information available to them in developing their plan of work, the question arises as to whether this requirement is sufficiently rigorous. An independent scientific evaluation of the applicant's plan of work may provide a more thorough and unbiased review.

\subsection{Best Environmental Practices}

The Advisory Opinion confirmed that States sponsoring exploration and exploitation activities in the Area must ensure that their contractors apply best environmental practices. ${ }^{31}$ Although the Seabed Disputes Chamber did not provide a definition of best environmental practices, other Conventions such as the 1992 Convention for the Protection of the Marine Environment of the North-East Atlantic (OSPAR Convention) define the concept of best environmental practices as "the application of the most appropriate combination of environmental control measures and strategies." 32 The OSPAR Convention further acknowledges that best environmental practices are dynamic providing that "best

Marine Resources, the 1991 Protocol on Environmental Protection to the Antarctic Treaty and the 1979 Convention on the Conservation of Migratory Species of Wild Animals.

${ }^{30}$ Draft Exploitation Regulations, above note 9, Regulation 46(c).

${ }^{31}$ Advisory Opinion, above note 8, paragraphs 122 and 136.

${ }^{32}$ Convention for the Protection of the Marine Environment of the North-East Atlantic, (opened for signature 22 September 1992, entered into force 25 March 1998) (OSPAR Convention) 2354 UNTS 67, Appendix I, paragraph 6 . 
environmental practice ... will change with time in the light of technological advances, economic and social factors, as well as changes in scientific knowledge and understanding." 33 "Best environmental practices" are to be taken into account by the Authority, sponsoring States and contractors in planning, implementing and modifying measures necessary for ensuring the effective protection of the Marine Environment from harmful effects under article 145 of the Convention in respect of activities in the Area. 34 "Best environmental practices" are defined in Schedule 1 of the draft Exploitation Regulations as:

" the application of the most appropriate combination of environmental control measures and strategies taking into account the criteria set out in the applicable Guidelines ."

Further issues may need to be defined in the applicable Guidelines such as whether the contractor is obliged to adapt its mining operations to the developing requirements of "best environmental practices" including "best available technology" during the course of its exploitation contract.

\subsection{Access to Environmental Information}

Principle 10 of the Rio Declaration highlights the importance of access to environmental information and participatory rights in environmental decision making. It provides, inter alia:

"Environmental issues are best handled with the participation of all concerned citizens, at the relevant level. At the national level, each individual shall have appropriate access to information concerning the environment that is held by public authorities, including information on hazardous materials and activities in their communities, and the opportunity to participate in decision making processes. ...."

The key elements in Principle 10 are reflected in a number of international law instruments including the Aarhus Convention on Access to Information, Public Participation in Decisionmaking and Access to Justice in Environmental Matters, the Espoo Convention on EIA in a Transboundary Context and the Kiev Protocol on Strategic Environmental Assessment. ${ }^{35}$ The

\footnotetext{
${ }^{33}$ Ibid, Appendix I, paragraph 8.

${ }^{34}$ Draft Exploitation Regulations, above note 9, Regulation 46(b).

${ }^{35}$ Convention on Access to Information, Public Participation in Decision-making and Access to Justice in Environmental Matters (opened for signature 25 June 1998, entered into force 29 October 2001) (Aarhus
} 
draft Exploitation Regulations incorporate substantial provisions on access to environmental information including a fundamental principle on promotion of access to environmental information, consultation during the EIA process, public notification of application for approval of a plan of work and access to the EIS, EMMP and CP. ${ }^{36}$

\subsection{Polluter Pays Principle}

The polluter pays principle means that the polluter bears the expense of carrying out measures to ensure that the environment is in an acceptable state. ${ }^{37}$ The costs envisaged are those associated with pollution control, clean up and protection measures. Principle 16 of the Rio Declaration provides:

"National authorities should endeavour to promote the internalisation of environmental costs and the use of economic instruments, taking into account the approach that the polluter should, in principle, bear the cost of pollution, with due regard to the public interest and without distorting international trade and investment“"

A number of treaties relating to marine environmental protection have incorporated the polluter pays principle although some of the relevant provisions are couched in advisory rather than mandatory terms. ${ }^{38}$ While the polluter pays principle can be considered as a general principle of international law which should be taken into account in the development of environmental law and policy, its normative character is still in debate. ${ }^{39}$ Regulation 47 of the draft Exploitation Regulations provides that:

\footnotetext{
Convention) 2161 UNTS 447; Convention on Environmental Impact Assessment in a Transboundary Context (opened for signature 25 February 1991, entered into force 27 June 1997) (Espoo Convention) 30 ILM 802; Protocol on Strategic Environmental Assessment to the Convention on Environmental Impact Assessment in a Tranboundary Context (opened for signature 21 May 2003, entered into force 11 July 2010) 2685 UNTS 140.

${ }^{36}$ Draft Exploitation Regulations, above note 9, Regulations 2(5)(d), 11 and 14.

${ }^{37}$ Patricia Birnie, Alan Boyle and Catherine Redgwell, International Law and the Environment (Third Edition) (Oxford University Press, 2009) 322; Robin Churchill, "The LOSC regime for the protection of the marine environment - fit for the twenty-first century?" in R. Rayfuse (ed.) Research Handbook on International Marine Environmental Law (Routledge, 2015) 10.

${ }^{38}$ Birnie, Boyle and Redgwell, above note 37, 323. The treaties with mandatory provisions on polluter pays include the OSPAR Convention, the 1992 Helsinki Convention on the Protection of the Marine Environment of the Baltic Sea Area and the 1995 Barcelona Convention for the Protection of the Marine Environment and the Coastal Region of the Mediterranean.

${ }^{39}$ Ibid.
} 
"A Contractor shall take necessary measures to prevent, reduce and control pollution and other hazards to the Marine Environment from its activities in the Area, in accordance with the Environmental Management and Monitoring Plan and the applicable Standards and Guidelines."

Under the Section 7.1 of the Standard Clauses for an exploitation contract contained in Annex $\mathrm{X}$ of the draft Exploitation Regulations:

"The Contractor shall be liable to the Authority for the actual amount of any damage, including damage to the Marine Environment, arising out of its wrongful acts or omissions, and those of its employees, subcontractors, agents and all persons engaged in working or acting for them in the conduct of its operations under this Contract, including the costs of reasonable measures to prevent and limit damage to the Marine Environment...."

\section{$3 \quad$ Legal Thresholds in Deep Seabed Mining}

\subsection{Legal Thresholds for Taking Precautionary Action}

In the context of deep seabed mining, legal thresholds have mainly been discussed in terms of the point at which precautionary actions need to be taken during exploration and exploitation activities to prevent harm to the marine environment. In implementing the precautionary approach, it is important to establish where the legal threshold lies for applying precaution at different stages of the exploration and exploitation process. Jaeckel comments: "the precautionary approach comprises three elements, namely (a) a threat of environmental harm, (b) uncertainty, and (c) remedial action. In order to trigger the obligation to take remedial action, however, a certain threshold of risk, that is gravity times probability of harm, must be reached." ${ }^{40}$ Once the thresholds for gravity and probability of environmental harm are reached, the precautionary approach requires that measures to prevent environmental degradation be taken. The setting of such thresholds is designed to eliminate the possibility of taking precautionary action for minor or negligible threats of environmental harm. ${ }^{41}$ Precautionary measures must also be proportional to the desired level of environmental protection. In the context of exploitation activities in the Area, a proportionality test would

\footnotetext{
${ }^{40}$ Jaeckel, above note 7, 180.

${ }^{41}$ Ibid
} 
need to take into account the long term ecological and resource development objectives of the Authority and its member States.

The Exploration Regulations capture the general threshold for applying precaution in regulation 31(2) of the Nodules Regulations and regulation 33(2) of the Sulphides and Crusts Regulations with the words: "In order to ensure effective protection for the marine environment from harmful effects which may arise from activities in the Area." This wording is borrowed from Art 145 of the LOSC. In addition, the Seabed Disputes Chamber in the Advisory Opinion, incorporated a lower threshold for States to apply the precautionary approach as an element of due diligence where there are plausible indications of potential risks. The LOSC and Exploration Regulations set a higher threshold, that of serious harm, for particularly far-reaching measures, such as emergency orders to suspend or adjust operations to prevent serious harm to the marine environment from activities in the Area, disapproval of areas for exploitation by contractors in cases where substantial evidence indicates the risk of serious harm and in relation to the prescription of provisional measures in a dispute to prevent serious harm to the marine environment. "Serious harm" is defined in regulation 1 of both the Nodules and Sulphides and Crusts Regulations as:

"Any effect from activities in the Area on the marine environment which represents a significant adverse change in the marine environment determined according to the rules, regulations and procedures adopted by the Authority on the basis of internationally recognized standards and practices."

The question then arises as to how to determine what constitutes a significant adverse change in the marine environment. Levin et al comment: "In the context of deep seabed mining, ecological thresholds should help to inform the determination of when an adverse change and/or impact may be considered a significant one, i.e. serious harm. ${ }^{" 43}$ The determination of such ecological thresholds, however, is based on "long term average baseline conditions and natural ecological variability." 44 Levin et al do provide a range of other indicators which could be used to determine the likelihood of significant adverse changes and impacts at

\footnotetext{
${ }^{42}$ LOSC articles 162(2) (w) and (x) and 290(1).

${ }^{43}$ Lisa A. Levin, Kathryn Mengerink, Kristina M. Gjerde, Ashley A. Rowden, Cindy Lee Van Dover, Malcolm R. Clark, Eva Ramirez-Llodra, Bronwen Currie, Craig R. Smith, Kirk N. Sato, Natalya Gallo, Andrew K. Sweetman, Hannah Lily, Claire W. Armstrong, Joseph Brider, 'Defining "serious harm" to the marine environment in the context of deep-seabed mining' 74 Marine Policy (2016) 248.

${ }^{44}$ Ibid.
} 
species, ecosystem and community level including measures of biodiversity, abundance, habitat quality, population connectivity, heterogeneity levels and community productivity. ${ }^{45}$ They argue that the lack of baseline data necessary to determine ecological thresholds should lead to heightened restrictions on commercial scale exploitation activities and that activities in the Area should only take place if they do not cause serious harm to the marine environment. $^{46}$

The threshold of serious harm is not specifically used in the LOSC or the current ISA Mining Code in connection with the approval or denial of a plan of work for exploration in the Area. In the context of approving or rejecting a plan of work for exploitation, the threshold for taking precautionary action is not necessarily the same question as determining the threshold for serious harm to the marine environment during the course of an exploitation contract. This is because applying precaution in the approval process for an exploitation contract, requires a sequence of steps, including EIA, assessment of alternative options and transparent decisionmaking. These steps are required as soon as the general threshold for precaution is met. However, the application of these precautionary steps would not automatically result in rejection of an application. Instead, amending the plan of work and/or changing the location of the mining operation may be an option to lower the environmental risks to an acceptable level. If that is not possible, rejection of a plan of work may be required. The next section of the paper will consider some factors related to establishing the threshold for approving or rejecting a plan of work for exploitation activities in the Area.

\subsection{Legal Threshold for Approving or Denying a Plan of Work for Exploitation}

A general threshold that could be applied to approving or rejecting a plan of work for exploitation is whether the applicant demonstrates an effective system to protect the marine environment from the harmful effects of exploitation activities. This threshold reflects the wording of Article 145 of the LOSC and aligns with the environmental protection responsibility of the Authority. This would require both the applicant and Authority to engage in a very thorough identification of the risks and uncertainties of the proposed exploitation activities for the marine environment of the Area and proposed plans to address these risks and uncertainties. Precautionary actions by the Authority such as imposing further conditions

\footnotetext{
${ }^{45}$ Ibid.

${ }^{46}$ Ibid, 256.
} 
that the applicant is required to meet before approval of a plan of work or rejection of a plan of work may be required. Ideally these would be based on recommendations by the LTC in accordance with a set of objective criteria set out in the Exploitation Regulations.

Implementing this threshold consistently with international environmental law principles, would require applicants, to conduct an EIA in accordance with established international norms and practice and on the basis of that assessment, to develop and submit environmental management plans and a system to address any harmful effects on the marine environment of the Area. The adequacy of the EIA and environmental management plans would then need to be assessed against a set of objective criteria approved by the Authority to measure whether the plan of work meets the requirement of effective protection of the marine environment from the harmful effects of exploitation activities. The draft Exploitation Regulations currently provide that the EIS submitted by an applicant for a plan of work should include an environmental risk assessment in accordance with good industry practice. ${ }^{47}$ This requirement and the requirement that uncertainties need to be identified and communicated during all stages of the EIA process are in themselves important components in ensuring effective protection of the marine environment of the Area from potential harmful effects. This could be improved by developing and publishing a set of objective criteria against which the applicant's EIA, EMMS and CP could be assessed to determine whether it meets the requirement of effective protection of the marine environment from the harmful effects of exploitation activities. A further safeguard for effective protection of the marine environment from the harmful effects of exploitation activities would be to ensure that strategic environmental assessment and regional environmental management plans are conducted and established before individual contracts are issued with the provision for adaptive management as the exploitation contract proceeds.

\section{Conclusion}

The most recent draft Exploitation Regulations issued by the LTC for the July 2018 session of the ISA represent a more comprehensive incorporation of international environmental law principles and widely accepted approaches to environmental management than is evident in the current Mining Code for the exploration phase. Nevertheless, there is still scope to expand on and make more specific the obligations of exploitation contractors to ensure they comply with the principles and approaches

\footnotetext{
${ }^{47}$ Draft Exploitation Regulations, above note 9, Regulation 46 bis (3)
} 
considered in this article. The regulations for the exploitation phase should also incorporate a more extensive and inclusive process of identifying and evaluating risks to the marine environment at the application for a plan of work stage. Within that process there should be ample opportunities for the LTC to take precautionary measures including requesting further information, imposing further conditions on the applicant or even rejecting an application for a plan of work where the applicant cannot demonstrate an effective plan to address harmful effects to the marine environment against a set of objective criteria. The further refinement of the exploitation code to meet the highest standards of effective protection of the marine environment from the harmful effects of exploitation activities will be a work in progress for the Authority as the commercial phase of deep seabed mining evolves. 